\title{
The mental workload analysis of safety workers in an Indonesian oil mining industry
}

\author{
Sri Indrawati, Atyanti Dyah Prabaswari*, and Tasya Pradipta \\ Industrial Engineering, Universitas Islam Indonesia, Yogyakarta, Indonesia
}

\begin{abstract}
The responsibilities of occupational health and safety workers are very hard to ensure other workers is safety. The responsibility make the workers of occupational health and safety has some affecting to their job. Some effect can cause over the mental workload. This research aims to determine the score of mental workload from three professions in occupational health and safety, i.e. safetyman contractor, safetyman field and safetyman officer. Six indicators in the NASA-TLX method, i.e. mental demand (MD), physical demand (PD), temporal demand (TD), performance (OP), effort (EF) and frustration level (FR) are used to determine the worker's mental workload. The result shows mental demand (MD) is the most dominant indicators affecting the mental workload between safetyman contractor, safetyman field and safety officer. The highest mental workload score among safety workers is on the safetyman field with WWL score at 62,38, because among the three types safety workers, the highest MD is on the safetyman field due to the responsibility.
\end{abstract}

\section{Introduction}

The rapid development of industrialization and technological innovation creates a tight competition between industries. In this case, each industry required to perform a better manufacturing performance. Human resources management plays a vital role for manufacturing excellence. Human resources are the main assets of the company in improving products quality [1]

[2] states that workers involvement in industry have an important role in the sustainability of industry's business. The right people in the right places at the right time with the right policies is the key of an industrial success [3]. Based on that research, 56\% industry in Slovakia consider the human resources for increasing productivity. An effective workload planning by optimizing workers capacity should be done to improve productivity [4]. Employee dissatisfaction and excessive mental workload are two main factors that can reduce the employee productivity in 21 st century [5].

The worker fatigue conditions can decrease productivity level of each worker [6]. An excessive workload leads to physical, mental and emotional fatigue, i.e. headaches, indigestion and irritability [7]. There are some factors that affecting worker productivity, i.e. age $(25 \%)$, gender $(15 \%)$, work tenure $(10 \%)$ and $50 \%$ workload and fatigue [8]. Various factors have successfully increase a worker productivity, i.e. a workload based salary, interesting job, career path, policies and work characteristics [9]. There are four factors that influenced the worker productivity in a musical instrument production, i.e. job stress $(23,5 \%)$, work motivation $(25,55)$, nutritional status $(25,5 \%)$ and workload $(25,5 \%)$ [10].

Generally, workers get workload both physically and mentally. Mental workload have a more significant relations with the musculoskeletal problem (neck and upper back) [11]. Mental workload consisting of some factors that influence the worker's mental processing of information, decision making process and individual reactions [12]. Some factors, i.e. worker age, gender, martial status, type of duties and profession have a positive relationship with mental workload [13]. The NASA Task Load Index (NASA-TLX) is a method for subjective mental workload measurement that broadly used in both manufacturing and service industry [14]. The integration of NASA-TLX and the goals, operators, methods and selection rules (GOMS) model is successfuly used to evaluate mental workload in human computer interaction process [15]. NASA-TLX also used to evaluate mental workload in electrical power control and operations center in Portugal and Northteast Brazil [16]. The research give some action plan to reduce a human error operation, economic losses, physical damage and treats to worker life. NASA-TLX is used to validate the result of a novel electroencephalography (EEG) approach [17]. This research is done to estimate task mental workload in constructions project.

In an Indonesian oil mining industry, the need to evaluate mental workload is increasingly important. Workers safety and health both mentally and physically are managed by an occupational health and safety department. The workers in that department are work to assure other workers use personal protective equipment (PPE) for work safety. Based on observation in that area

\footnotetext{
* Corresponding author: atyanti.dyah@uii.ac.id
} 
and interview some worker, sometimes this work is very hard and complicated due to other workers resistance, ignorance and defensiveness. A mental workload analysis is needed to improve worker productivity in occupational health and safety department. So, researcher want to examine mental workload of three jobs position in occupational health and safety department. The three jobs position are safety contractor, safetyman, and safety officer.

\section{Basic Theory}

\subsection{Mental Workload}

Mental workload is a working condition where there is information needs to be processed in the brain that requires a creativity [18]. Mental workload can be evaluated from the difference between the workload demands of a task and the maximum capacity of a workers mental load in a motivated condition. An excessive mental workload will lead to job stress such as fear, anxiety, guilt, anger sad, despair and boredom [19]. Stoner (1986). Different jobs for each worker will cause different levels of work stress [20]. There are several symptoms as the impact of excessive mental workload, i.e.: physical symptoms such as headache and abdominal pain, mental symptoms such as easy to forget, difficulty concentrating, anxious, irritable and desperate [21]. The last symptom is behavior such as smoking, drinking alcohol and avoiding others people.

\subsection{NASA-TLX}

Measurement method in subjective workload is a measurement of mental workload based on perceptions of respondent/workers of mental workload in subjective perspective, i.e. [22]:

a. National Aeronautics and Space Administration Task Load Index (NASATLX)

b. Subjective Workload Assessment Technique (SWAT)

c. Modified Cooper Harper Scaling

d. Multi-descriptor Scale

e. Rating Scale Mental Effort (RSME)

Some method to measurement mental workload from subjective perspective which more used and give good result is NASA-TLX and SWAT [23]. This method is measuring mental workload from the types of job, not measuring mental workload from the workers.

The NASA-TLX method is a method used to analyze the mental workload faced by workers who must perform various activities to finish the job. There are six main steps of NASA-TLX, i.e. (Hancock and Meshkati, 1988):

a. Weighting, in which section respondents are asked to choose one dominant to cause a mental workload.

b. Rating for six mental workload indicators.

c. Product scoring is done by multiplying the rating with factor weight for each descriptor. This is done for six mental workload indicators.

d. Weighted workload (WWL) that is derived by summing up the six product values. e. Average of WWL that calculated by dividing WWL by total weight.

f. Interpretation scores of average WWL using Table 1.

Table 1. The interpretation score of workload

\begin{tabular}{|l|l|}
\hline Workload & Value \\
\hline Low & $0-9$ \\
\hline Medium & $10-29$ \\
\hline Somewhat high & $30-49$ \\
\hline High & $50-79$ \\
\hline Very high & $80-100$ \\
\hline
\end{tabular}

\section{Research Method}

This research is done for workers that work in an occupational health and safety department of an Indonesian oil mining industry to evaluate the mental workload. Three types of profession are evaluated, i.e. safetyman contractor, safetyman field and safetyman officer. Six indicators of NASA-TLX method, i.e. mental demand (MD), physical demand (PD), temporal demand (TD), performance (OP), effort (EF) and frustration level (FR). MD is an indicator of how much mental and perceptual activity it takes to see, remember and search. Besides how kind of work is done (difficult, simple or complex). PD is related to the amount of physical activity required. TD is used to evaluate working time. The working time that felt slow, relax or fast and tired. OP is an indicator to analyze a person succeeds in doing job and how satisfied with the results. FR is related how insecure, hopeless, offended and disturbed feeling in doing a job. $\mathrm{EF}$ is an indicator how hard work is needed to reach the target.

The data are collected through direct observation, interview, and a survey using NASA-TLX questionnaire. A survey is done for each worker in occupational health and safety department with 30 respondents. NASA-TLX questionnaire is used for mental workload assessment. After data collection is done, data processing is performed to determine the value of mental workload of each operator using NASA-TLX method and statistical test. A mental workload analysis is developed for each NASATLX indicators. The NASA TLX steps used in this research are:

a. Weighting

Comparing for each factor, which more important to worker as seen in Table 2. Compare using every two factor. Example MD comparing to PD, MD comparing to $\mathrm{TD}, \mathrm{MD}$ comparing to $\mathrm{OP}, \mathrm{MD}$ Comparing to $\mathrm{EF}$, MD comparing to FR. And if comparing MD to every factor is done, weighting can continued to other factor, example PD comparing to each other factor. So, the total number of factor which chosen is 15 .

b. Rating

Worker giving the rating to six factor which influencing the mental workload. The rating has subjective poin of view because the perception ech worker.

c. Product score 
Product $=$ rating $\mathrm{x}$ weighting

The result of product can get from multiplication of weghting and rating.

d. Weighted Workload (WWL)

The result of WWL is sum of all product score.

e. Average of WWL

Score of WWL divided 15.

Table 2. Comparing factor

\begin{tabular}{|c|l|l|l|l|l|l|}
\hline & MD & PD & TD & OP & EF & FR \\
\hline MD & & & & & & \\
\hline PD & & & & & & \\
\hline TD & & & & & & \\
\hline OP & & & & & & \\
\hline EF & & & & & & \\
\hline FR & & & & & & \\
\hline
\end{tabular}

\section{Result and Discussion}

\subsection{Result}

The research shows that the average recapitulation of weighted workload (WWL) for three types of profession in occupational health and safety department is categorized as high as seen in Table 3. The safetyman field have a highest mental workload at score 62,38. Followed by mental workload of safetyman contractor with WWL score is 56,23 . The last is the safety officer with an average result at 54,5. Mental demand (MD) is the greatest indicators affecting the WWL score for all type of profession. It means that a great mental and perceptual activity needed to see, remember and searching are occurs.

MD values are equally high in value compared to other categories. This condition indicates a big responsibility for ensuring workers to work safely and try to reduce the number of accidents. The highest mental demand is on the safetyman field due to the responsibility for a large oil refinery area and an urgent condition of safetyman straight down the spaciousness to finish the problems related to damaged equipment, gas leaks and fires. The other task and responsibility is to intervene on unsafe conditions /actions. This tasks and responsibilities becomes harder due to some arrogant workers.

A high physical demand value (PD) also obtained on the safetyman field because this profession should travel around the field in all working hours. The fatigue possibility occurs because of other additional task, i.e. check the PPE compliance report, a report of good housekeeping (GHK) compliance and also for hazardous and toxic materials. Besides that the safetyman field also check permit to work (PTW) document that consist of a requirement to perform dangerous tasks with regard there are potential hazards and preventive.

The temporal demand (TD) score for safety officer is the highest at 197. It is caused by responsibilities to follow-up the safety field document result with intervention, evaluation and monitoring in a short time.
The safety officer always make some analysis and evaluation as well as prepare data for improvement program.

Table 3. The recapitulation of WWL and interpretation score

\begin{tabular}{|c|c|c|c|c|c|c|}
\hline \multirow{2}{*}{$\begin{array}{c}\text { Catego- } \\
\text { ry }\end{array}$} & \multicolumn{2}{|c|}{$\begin{array}{c}\text { Safetyman } \\
\text { contractor }\end{array}$} & \multicolumn{2}{c|}{$\begin{array}{c}\text { Safetyman } \\
\text { field }\end{array}$} & \multicolumn{2}{c|}{$\begin{array}{c}\text { Safetyman } \\
\text { officer }\end{array}$} \\
\cline { 2 - 8 } & Total & $\begin{array}{c}\text { Aver } \\
\text { age }\end{array}$ & Total & $\begin{array}{c}\text { Aver } \\
\text { age }\end{array}$ & $\begin{array}{c}\text { Tot } \\
\text { a }\end{array}$ & $\begin{array}{c}\text { Avera } \\
\text { ge }\end{array}$ \\
\hline MD & 2080 & 208 & 2302 & 230,2 & $\begin{array}{c}202 \\
5\end{array}$ & 202,5 \\
\hline PD & 1030 & 103 & 1156 & 115,6 & 985 & 98,5 \\
\hline TD & 1600 & 160 & 1781 & 178,1 & $\begin{array}{c}197 \\
0\end{array}$ & 197 \\
\hline OP & 1525 & $\begin{array}{c}152, \\
5\end{array}$ & $\begin{array}{c}1679, \\
5\end{array}$ & 167,9 & 895 & 89,5 \\
\hline EF & 2040 & 204 & 2244 & 224.4 & $\begin{array}{c}181 \\
0\end{array}$ & 181 \\
\hline FR & 160 & 16 & 195 & 19.5 & 490 & 49 \\
\hline $\begin{array}{c}\text { WWL } \\
\text { Average }\end{array}$ & 56,23 & \multicolumn{2}{|c|}{62,38} & \multicolumn{2}{|c|}{54,5} \\
\hline $\begin{array}{c}\text { Catego- } \\
\text { ry }\end{array}$ & \multicolumn{2}{|c|}{ High } & \multicolumn{2}{|c}{ High } & \multicolumn{2}{|c|}{ High } \\
\hline
\end{tabular}

Based on the average results for performance (OP), the safety officer get a best score at 89,5 . This condition is caused by a work support from safety field who always try to supervise the workers in oil refining areas. For effort indicator (EF), safety field obtain a high value at 224,4. The safetyman field always trying to solve existing problems and help the workers to reach target in oil refining areas. The frustration level (FR) for safety officer becomes the highest because a big responsibility related to any safety or accident problems that must be resolved.

Based on mental workload assessment result using NASA-TLX, an improvement program is proposed to reduce mental workload risk. The improvement program consist of some activity, i.e. $5 \mathrm{~S}$ program (seiri, seiton, seiso, seiketsu and shitsuke) for workplace improvement design, improvement of communication pattern to be more effective and focused on problem solving, occupational stress management and some informal activities. The occupational stress management for the department leaders should be done so that leaders get a better understanding in some causes and early symptons of work stress and how to to minimize the cause. Informal activities is done with the aim of improving relaxation and relationships among workers. Some informal activities that can be done include happy hours, afternoon tea, outbound activities, and family gathering. Workers have some positive responses from relaxation exercises that stress can be reduced, reduced mental burden, body and soul become fresher and fitter, good for health, and feel more calm [22].

\section{Conclussion}

The research shows that safetyman field have a highest mental workload with WWL score of 62,38 and including in high category. The most dominant indicators affecting the mental workload between safetyman contractor, safetyman field and safety officer is mental demand 
(MD). Among the three types safety workers, the highest MD is on the safetyman field due to the responsibility for a large oil refinery area and an urgent condition of safetyman straight down the spaciousness to finish the problems related to damaged equipment, gas leaks and fires. The highest MD caused by an indicator of how much mental and perceptual activity it takes to see, remember and search. Safetyman field have the highest value of MD score 203,2 . This is due to the great responsibility for the safety and security of workers.

Researchers thank to the support of Industrial Engineering Department, Faculty of Industrial Technology, Universitas Islam Indonesia.

\section{References}

1 Setyawati, L.S., Selintas tentang kelelahan kerja, Amara Books, Yogyakarta, (2010)

2 Schroeder, H., The Importance of Human Resource Management in Strategic Sustainability: An Art and Science Perspective, Journal of Environmental Sustainability, Vol. 2. Issue 2: 75-82, (2012).

3 Koltnerova, K., Chlpekova, A., Samakova, J., The Importance of Human Resource Planning in Industrial Enterprises, Research Papers Faculty of Materials Science and Technology Slovak University of Technology, Vol. 20: 62-67, (2012)

4 Berseneva, K.V., Natsubidze, A.S., Chaschin, V.V., Human Resource Planning in Implementation of Industrial Enterprises' Strategy, World Applied Sciences Journal, Vol. 29 (3): 433-437, (2014)

5 Aslam, H.D., Aslam, M., Ali, N., Habib., B.,. Importance of Human Resource Management in 21st Century: A Theoretical Perspective, International Journal of Human Resource Studies, Vol. 3, No. 3: 8796, (2013)

6 Ulfah, N., Nurcahyo, J., \& Dwiandhono, I., Model Kuantitatif Manajemen Kelelahan dan Beban Kerja untuk Peningkatan Produktivitas Pekerja Penggilingan Padi, Jurnal Kesehatan Masyarakat Nasional, Vol.7. No.10: 477-480, (2013)

7 Manuaba, A., \& Sriwatomo, W., Ergonomi untuk keselamatan, kesehatan kerja dan produktivitas, UNIBA PRESS, Surakarta, Indonesia, (2000)

8 Katsuro P.C., Gadzirayi, Taruwona M, \& Suzanna M., Impact of occupationalhealth and safety on worker productivity: a case of Zimbabwe food industry, African journal of Business Manajement, Vol. 4, No.13: 2644-2651, (2010)

9 Adnyani, I.G., Membina semangat kerja untuk meningkatkan produktivitas kerja karyawan, Jurnal Studi Ekonomi Universitas Udayana, Vol. 13, No.2: 202-209, (2008).

10 Reniati R. A., Faktor-faktor yang mempengaruhi produktivitas kerja pada pekerja bagian pembuatan drum unit drum plant PT X 2006, Tesis Universitas Diponegoro, Universitas Diponegoro, (2006)
11 Larsman, P. \& Hanse, J.J., Psychological and Physical Workload and the Development of Musculoskeletal Symptoms Among Female Elderly-Care Workers, The Ergonomics Open Journal, Vol. 1: 34-38, (2008)

12 Sartang, G., Ashnagar, M., Habibi, E., Sadeghi, S., Evaluation of Rating Scale Mental Effort (RSME) effectiveness for mental workload assessment in nurses, Journal of Occupational Health and Epidemology, Vol.5. Issue 4: 211-217, (2016)

13 Seker, A., Using Outputs of NASA-TLX for Building a Mental Workload Expert System, Gazi University Journal of Science, Vol. 27. No. 4: 1131-1142, (2014)

14 Cao, A., Chintamani, K.K., Pandya, A.K., Ellis, D., NASA TLX: Software for assessing subjective mental workload, Behavior Research Methods, Vol 41. Issue 1: 113-117, (2009)

15 Ramkumar, A., Stappers, P.J., Niessen, W.J., Adebahr, S., Schimek-Jasch, T., Nestle, U., Song, Y., Using GOMS and NASA-TLX to Evaluate HumanComputer Interaction Process in Interactive Segmentation, International Journal of HumanComputer Interaction, Vol. December 2016: 1-12, (2016)

16 Melo, M.O., Silva, L.B., Rebelo, F.S, Ergonomics Aspects And Workload On The Operators In The Electric Power Control And Operation Centers: MultiCase Studies In Portugal And Brazil, Iberoamerican Journal of Industrial Engineering, Volume 8 No. 16: 35-55, (2016)

17 Chen, J., Taylor, J.E., Comu, S., Assessing Task Mental Workload in Construction Projects: A Novel Electroencephalography Approach, Journal of Construction Engineering and Management, Vol. 143. Issue 8: 4017053, (2017)

18 Khroemer, K.H.E. \& Grandjean, E., Fitting the Task to Human. $6^{\text {th }}$ edition, CRC Press, USA, (1997)

19 Fraser, P., Stres dan Kepuasan Kerja, Erlangga, Jakarta, (1992).

20 Rauf, F., Analisis Beban Mental Menggunakan Metode National Aeronautics And Space Administration-Task Load Index (Nasa-Tlx) Di PPPPTK Bmti Di Departemen Mesin Bandung, Tugas Akhir Universitas Komputer Indonesia, Indonesia. (2012)

21 Hancock, P. A. \& Meshkati, N., Human Mental Workload, Advances in psychology, Elsevier Science Publisher, Netherlands, (1988)

22 Widyanti, A., Johnson, A. \& Waard, D.d. 2010. Pengukuran Beban Kerja Mental Dalam Searching Task Dengan Metode Rating Scale Mental Effort (RSME). JTI Universitas Diponegoro, 1(V).

23 Puspawardhani, E. H., Suryoputro, M. R., Sari, A. D., Kurnia, R. D., \& Purnomo, H., Mental Workload Analysis Using NASA-TLX Method Between Various Level of Work in Plastic Injection Division of Manufacturing Company, Advances in Safety Management and Human Factors, Vol. July 27-31 2016: 311-319, (2016) 